\title{
Plant zonation in a tropical irregular estuary: can large occurrence zones be explained by a tradeoff model?
}

\author{
Ribeiro, JPN. ${ }^{a *}$, Matsumoto, RS. ${ }^{a}$, Takao, LK. ${ }^{a}$ and Lima, MIS. ${ }^{a}$ \\ aPrograma de Pós-graduação em Ecologia e Recursos Naturais, Universidade Federal de São Carlos - UFSCar, \\ Rodovia Washington Luís, Km 235, CP 676, CEP 13565-905, São Carlos, SP, Brazil \\ *e-mail: jpnr@jpnr.com.br
}

Received: July 25, 2013 - Accepted: November 12, 2013 - Distributed: August 31, 2015

\begin{abstract}
Estuaries present an environmental gradient that ranges from almost fresh water conditions to almost marine conditions. Salinity and flooding are the main abiotic drivers for plants. Therefore, plant zonation in estuaries is closely related to the tidal cycles. It is expected that the competitive abilities of plants would be inversely related to the tolerance toward environmental stress (tradeoff). Thus, in estuaries, plant zonation tends to be controlled by the environment near the sandbar and by competition away from it. This zonation pattern has been proposed for regular non-tropical estuaries. For tropical estuaries, the relative importance of rain is higher, and it is not clear to what extent this model can be extrapolated. We measured the tidal influence along the environmental gradient of a tropical irregular estuary and quantified the relative importance of the environment and the co-occurrence degree. Contrary to the narrow occurrence zone that would be expected for regular estuaries, plants presented large occurrence zones. However, the relative importance of the environment and competition followed the same patterns proposed for regular estuaries. The environmental conditions allow plants to occur in larger zones, but these zones arise from smaller and infrequent patches distributed across a larger area, and most species populations are concentrated in relatively narrow zones. Thus, we concluded that the zonation pattern in the Massaguaçu River estuary agrees with the tradeoff model.
\end{abstract}

Keywords: competition, distribution pattern, salt, soil waterlogging, tidal environments.

\section{Zonação vegetal em um estuário tropical irregular: amplas zonas de ocorrência podem ser explicadas por um modelo tradeoff?}

\section{Resumo}

Estuários apresentam um gradiente ambiental que varia de condições próximas a de água doce a condições quase marinhas. A salinidade e o alagamento são os principais fatores abióticos para as plantas. Por isso, a zonação vegetal em estuários está proximamente relacionada aos ciclos da maré. É esperado que as habilidades competitivas das plantas sejam inversamente relacionadas à tolerância ao estresse ambiental (tradeoff). Assim, em estuários, a zonação vegetal tende a ser controlada pelo ambiente, próximo à barra, e pela competição, longe da mesma. Esse padrão de zonação tem sido proposto para estuários regulares não tropicais. Para estuários tropicais, a importância relativa da chuva é maior, e não é claro até que ponto esse modelo pode ser extrapolado. Nós medimos a influência da maré ao longo do gradiente ambiental de um estuário tropical irregular e quantificamos a importância relativa do ambiente e o grau de correlação. Contrariamente à ocorrência estreita que seria esperada para estuários regulares, as plantas apresentaram amplas zonas de ocorrência. No entanto, a importância relativa do ambiente e da competição seguiram os mesmos padrões propostos para estuários regulares. As condições ambientais permitem às plantas ocorrerem em zonas mais amplas, mas estas zonas resultam de pontos ocasionais, e as populações da maioria das espécies estão concentradas em zonas relativamente estreitas. Desse modo, concluímos que o padrão de zonação no estuário do Rio Massaguaçu está de acordo com o modelo tradeoff.

Palavras-chave: interações, padrão de distribuição, sal, alagamento de solo, ambientes tidais.

\section{Introduction}

Estuaries are environment characterized by mixtures of river freshwater and ocean saltwater. When rivers and the ocean are permanently connected (regular estuaries), mixing of water occurs in a continuum, and therefore, is closely related to the tidal cycles. Sometimes, the ocean creates a sandbar that seals its connection to the river (irregular estuaries). In these cases, the tidal influence is limited because mixing of water only occurs when the 
sandbar breaches (Wolanski, 2007). Estuaries are delimited by saltwater influence over the freshwater at one extremity and by the freshwater influence over the saltwater at the other. Therefore, estuaries present an environmental gradient that ranges from almost freshwater conditions to almost marine conditions (King et al., 1990; Pennings and Callaway, 1992; Wolanski, 2007). In this gradient, the salinity and flooding cycles are widely recognized as the main abiotic drivers for plant community zonation (Greenwood and Macfarlane, 2009; Ribeiro et al., 2011a, 2013; Touchette, 2006). In non-halophytes plants, salt can lead to ionic toxicity, hormonal disturbance or both (Kozlowski, 1997). Flooding unchains a series of physical, chemical and biological changes in the soil that completely modify its ability to support plant growth (Kozlowski, 1997). Therefore, the plant zonation in tidal environments is mainly dependent upon the salinity and flooding cycles (Costa et al., 2003; Greenwood and Macfarlane, 2009; Pennings et al., 2005; Sorrell and Tanner, 2000).

Plant distribution and abundance along estuaries are indicative of species' tolerance toward environmental drivers and their competitive ability (Crain et al., 2004; Greenwood and Macfarlane, 2009). In harsh environments, the ability to cope with abiotic stress tends to be more important to plant zonation, whereas in benign environments, competitive ability appears to be the main driver (Crain et al., 2004; Greenwood and Macfarlane, 2009; Peyre et al., 2001). This zonation model predicts a tradeoff between competitive ability and stress tolerance (Grime, 1977). In an estuary, the relative importance of the environment drivers is expected to be higher near the sandbar, where the ocean saltwater inflow creates an inhospitable environment for most species. The tidal influence decreases and the environment becomes less limiting upward the estuary. With more species being physiologically able to inhabit the area, the importance of the competitive interactions increases. Thus, in estuaries, plant zonation is expected to be mainly controlled by abiotic drivers at their lower limits (higher tidal influence) and by biotic drivers at their upper limits (lower tidal influence) (Castillo et al., 2000; Ribeiro et al., 2011a; Ungar, 1998).

However, there are alternative models. It has been proposed that competition is more intense in harsh environments. The idea behind this model is that a smaller amount of resources would intensify the competitive process (Wiens, 1977). As it is implausible to expect that stress would increase competition for non-resource drivers (such as salt), this model is very unlikely to be successfully applied to estuaries. Another model predicts that the importance of competition is the same, regardless of environmental conditions (Newman, 1973; Tilman, 1982). According to this model, stressful conditions acts only modulating competition, but competitive interactions per se are equally important throughout the gradient (Peyre et al., 2001).

Most studies examining the relationship between abiotic gradients and biotic interactions in tidal environments have been conducted in regular estuaries in the medium and high latitudes of the Northern Hemisphere (Costa et al., 2003). In these environments, there is usually a clear and predictable pattern in plant distribution, and the species occur in relatively narrow zones, with little niche overlapping (Pennings and Callaway, 1992; Vince and Allison, 1984). This pattern supports the tradeoff model. In the tropics, higher rainfall leads to a higher relative importance of freshwater. This leads to an intermittency of salinity-mediated stress, which results in wider occurrence zones. Furthermore, in irregular estuaries the tidal effect is limited, and thus, the relative importance of freshwater is expected to be even higher (Costa et al., 2003). Still, sandbar breachings are usually disturbing and unpredictable events. Unpredictability is a severe stress to most plants (Otte, 2001) and tends to prevent a competitive balance from being reached, which leads to a under-utilization of resources and therefore to greater niche overlapping (Russell et al., 1985). Therefore, it is not clear to what extent the current models can be used to make predictions regarding tropical estuaries (Costa et al., 2003), particularly the irregular ones, and plant zonation along tropical estuary tidal gradients is one of the larger gaps in our knowledge about costal environments (Crain et al., 2004).

We performed this study in a tropical irregular estuary and expected that, in this environment, plants would present large occurrence zones. In consequence, we hypothesized that the importance of abiotic factors over plant assemblage would be constant along the estuarine gradient. In other words, we expected that the tradeoff model currently used to describe temperate estuaries would not apply to an irregular tropical estuary. To test this hypothesis, our objective was to (1) characterize the zonation patterns in an estuary and to (2) assess how that pattern is influenced by both environment and space.

\section{Material and Methods}

\subsection{Study site}

The Massaguaçu River estuary (23'37'20'S and $45^{\circ} 21^{\prime} 25^{\prime} \mathrm{W}$, Caraguatatuba, São Paulo, Brazil) is an irregular estuary, with a sandbar that breaches several times per year. The time between breaching events ranges from few days to more than a month The time that the sandbar remains opened also varies, from one tidal cycle to more than 15 days (see Ribeiro et al., 2013). There are five main macrophytes banks within the estuary (banks A, B, C, D and $\mathrm{E}$ ). From small herbaceous to trees, all species are fixed to the substrate, and banks have a relative stable plant assemblage. Bank B is an island, and the others are linked to the estuary's margin (Figure 1). The estuary is located in a region with a humid tropical climate ( $a f)$, a mild winter, rain in all months and no dry season (Peel et al., 2007).

Although the estuary's eastern margin had suffered several modifications by human action, it still presents riparian vegetation throughout almost all its extension. The right margin is better preserved, covered with Atlantic rain forest. The banks inside the estuary demonstrate dense formations of both aquatic and amphibious plants. 


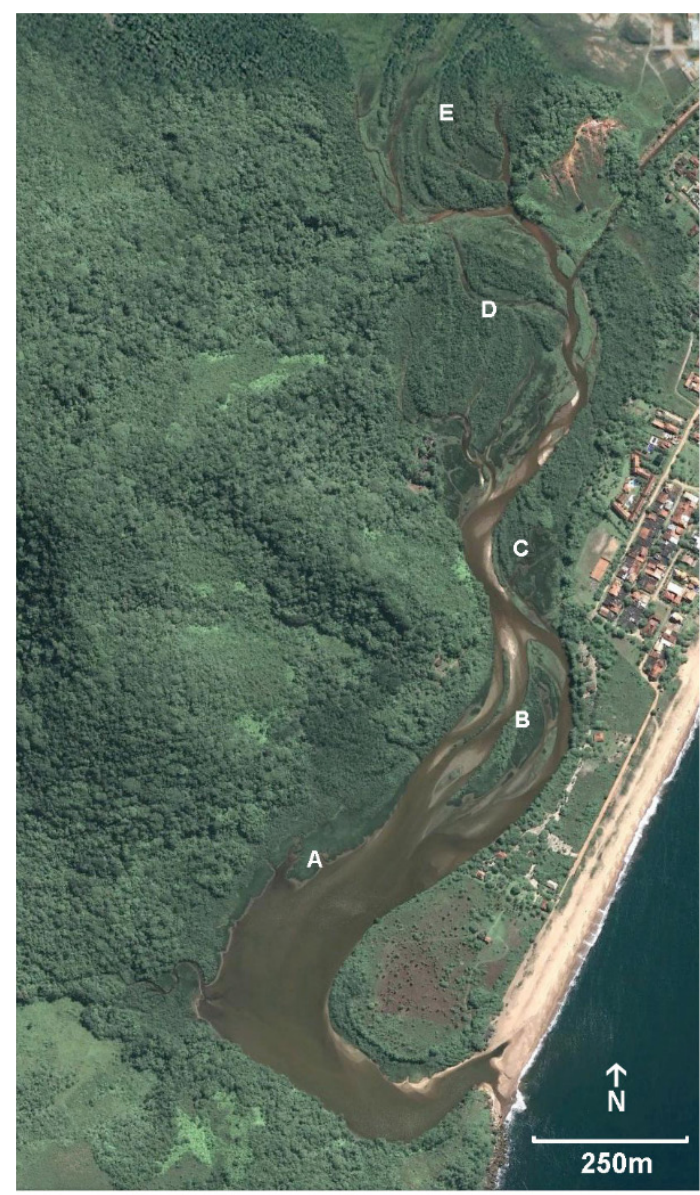

Figure 1. Aerial image of the Massaguaçu River estuary. The letters indicate the approximate locations of the macrophyte banks (extracted from Ribeiro et al., 2011b).

To the best of our knowledge, there are no studies on the estuary's conservation state, but there is also no history of direct disturbance in the last 30 years either. Sandbar breaching is a natural event, but man-made breaching is occurring more often, and the effects of this practice on the estuary flora are uncertain.

\subsection{Edaphic and floristic characterization}

Over an aerial image, we randomly chose 16 plots $(5 \times 5 \mathrm{~m})$ in each bank (total of 80 plots) and uploaded the plot locations into a GPS device for field localization. In the field, we registered the species cover $\left(\mathrm{m}^{2}\right)$ in each plot, collected a soil sample and determined the edaphic characteristic (organic matter, $\mathrm{pH}, \mathrm{P}, \mathrm{K}, \mathrm{Ca}, \mathrm{Mg}, \mathrm{H}+\mathrm{Al}, \mathrm{V} \%$, $\mathrm{Cu}, \mathrm{Fe}, \mathrm{Mn}, \mathrm{Zn}$ and salinity) and measured the relative plot height. To measure the estuary water level, we installed a graduated scale in the estuary, where the zero represented the lowest level that the estuary water can reach. Between June 2007 and June 2009, we took daily readings of the water level. We grouped the plots according to the time they were flooded during this period (see Ribeiro et al., 2011a for details).

\subsection{Data analysis}

For the floristic analysis, we used abundant species only (Ribeiro et al., 2011a). We arranged the dataset in a incidence matrix (with species presence/absence in rows and plots in columns) and used the checkerboard index (C-board) to calculate co-occurrence degree of the main species (Gotelli and Entsminger, 2001). This analysis calculates the number of species pairs that never occur together and can be used as a evidence of competition (Horner-Devine et al., 2007). In the R environment (R Development Core Team, 2008) using the package vegan, from a matrix in which rows represent species abundance and columns represent plots, we performed a variation partition (Laliberté et al., 2009) to determine the relative importance of the environment (edaphic and flooding) and the spatial autocorrelations in plant zonation through principal coordinates of neighbor matrices.

\section{Results}

\subsection{Estuary characterization}

The estuary presented a longitudinal saline gradient, with higher electric conductivity values near the sandbar and lower values upstream. The sodium ions $\left(\mathrm{Na}^{+}\right)$values follow the same pattern $\left(\mathrm{R}^{2}=0.39\right)$. Banks $\mathrm{A}$ and $\mathrm{B}$ had a wide range of salinity values, whereas banks $\mathrm{C}, \mathrm{D}$, and particularly E had a much narrow range. This indicated that in plots near the sandbar, there were several other factors that were important to determining plot salinity (e.g., plot elevation), whereas plots away from the sandbar usually had low salinity values. There is a slight increase in the banks' average height upstream. Therefore, there were more plots where flooding might be a limiting factor with bank A than bank E. Full estuarine edaphic characterization are available in annex 1 .

\subsection{Principal species}

We observed 51 species of aquatic and/or amphibious plants in the Massaguaçu River estuary and classified 12 of them as abundant (see Ribeiro et al., 2011b for the full inventory). Most species presented a relatively clear relation to salinity patterns. While Crinum americanum L., Bacopa monnieri (L.) Pennell, and Eleocharis flavescens (Poir.) Urb. were more abundant in the more saline areas, Eleocharis interstincta (Vahl) Roem. \& Schult., Scleria mitis P.J. Bergius, and Rhynchospora corymbosa (L.) Britton presented higher densities in less saline areas. Typha domingensis Pers. occurred only in the less saline portion of bank E. Acrostichum danaeifolium Langsd \& Fisch and Brachiaria mutica (Forssk.) Stapf were denser in intermediary saline conditions. Acroceras zizanioides (Kunth) Dandy, Echinochloa polystachya (Kunth) Roberty and Paspalum sp. did not present a clear zonation pattern along the saline gradient (Table 1).

\subsection{Co-occurrence}

The co-occurrence index values between most abundant species were smaller than expected by chance in the estuary salinity extremes: bank A and B (higher salinity) 
Table 1. Main estuary species and their distribution in the banks $\left(\mathrm{m}^{2} / 16\right.$ plots).

\begin{tabular}{llrrrrr}
\hline \multicolumn{1}{c}{ Species } & \multicolumn{1}{c}{ Family } & \multicolumn{1}{c}{ A } & \multicolumn{1}{c}{ B } & \multicolumn{1}{c}{ C } & D & E \\
\hline Crinum americanum L. & Amaryllidaceae & 163.34 & 124.57 & 122.30 & 125.11 & 60.63 \\
Eleocharis interstincta (Vahl) Roem. \& Schult. & Cyperaceae & 37.39 & 0.00 & 54.65 & 95.08 & 107.81 \\
Bacopa monnieri (L.) Pennell & Plantaginaceae & 93.26 & 71.98 & 37.51 & 14.43 & 0.00 \\
Acroceras zizanioides (Kunth) Dandy & Poaceae & 39.19 & 0.00 & 40.21 & 47.85 & 58.36 \\
Eleocharis flavescens (Poir.) Urb. & Cyperaceae & 83.41 & 22.48 & 13.42 & 4.12 & 0.00 \\
Rhynchospora corymbosa (L.) Britton & Cyperaceae & 31.72 & 0.00 & 8.14 & 2.51 & 62.64 \\
Acrostichum danaeifolium Langsd \& Fisch & Pteridaceae & 6.20 & 24.30 & 30.93 & 0.00 & 0.20 \\
Typha domingensis Pers. & Typhaceae & 0.00 & 0.00 & 0.00 & 0.00 & 53.62 \\
Paspalum sp. & Poaceae & 33.00 & 0.00 & 0.00 & 1.65 & 7.21 \\
Echinochloa polystachya (Kunth) Roberty & Poaceae & 0.00 & 8.77 & 1.03 & 25.96 & 2.83 \\
Brachiaria mutica (Forssk.) Stapf & Poaceae & 0.00 & 1.09 & 4.12 & 31.76 & 0.00 \\
Scleria mitis P.J. Bergius & Cyperaceae & 4.78 & 0.00 & 4.12 & 12.37 & 8.66 \\
\hline
\end{tabular}

Table 2. Co-occurrence of the most abundant estuary species. This analysis measured the number of times (expressed herein as $\%)$ the observed (obs) data presented a higher ( $\%$ obs $>\exp )$ or a lower $(\%$ obs $<\exp )$ number of chessboard pairs when compared with the simulated expected (exp) data. The higher the number of chessboard pairs in the observed data (i.e., the higher the \% obs > exp value) is, the smaller the observed co-occurrence. A, B, C, D and E are the macrophyte banks.

\begin{tabular}{rccrrr}
\hline & A & B & C & D & E \\
\hline \% obs $>\exp$ & 99.9 & 27.5 & 2.5 & 98.4 & 90.6 \\
\% obs $<\exp$ & 0.01 & 72.5 & 97.5 & 1.6 & 9.4 \\
\hline
\end{tabular}

Table 3. Environmental and spatial importance of plant zonation in the Massaguaçu River estuary. A, B, C, D and E are the macrophyte banks.

\begin{tabular}{lccccc}
\hline & A & B & C & D & E \\
\hline Environment $\left(\mathrm{R}^{2}\right.$ adjusted) & 0.43 & 0.34 & 0.17 & 0.20 & 0.01 \\
Space $\left(\mathrm{R}^{2}\right.$ adjusted) & 0.17 & 0.01 & 0.17 & 0.31 & 0.12 \\
\hline
\end{tabular}

and $\mathrm{D}$ and $\mathrm{E}$ banks (lower salinity). On the other hand, bank $\mathrm{C}$, which presented intermediary salinity, presented a co-occurrence index value that was higher than expected by chance (Table 2 ).

\subsection{Variation partition}

The higher the bank soil salinity was, the higher the environmental importance to plant zonation. Thus, the relative importance of the environment for plant assemblage was higher in bank A and almost null in bank E (Table 3). Spatial autocorrelation importance values were small and did not follow a pattern along the estuarine gradient.

\section{Discussion}

The higher importance of the environment, when compared to that of space for plant zonation in saltier banks suggests that the salt physiologically restrains the occurrence of several species in these banks (Castillo et al., 2000; Ribeiro et al., 2011a; Touchette, 2006). This salt limitation resulted in small co-occurrence index values. On the other hand, where there is almost no soil salinity, a great number of species are physiologically able to occur. With no salinity restraint, the environmental importance is reduced, and competitive interactions are expected to increase in relative importance. In the area of bank $\mathrm{E}$, where we observed the lowest salinity values, the environmental importance to plant community composition was almost null. However, the co-occurrence index value was low for this bank as well. These findings are consistent with the idea that in these zones the intensification of the competitive process would exclude species. In intermediate zones, the co-occurrence index value was high, which suggests that there is a balance between environmental stress tolerance and competitive ability (Pennings and Callaway, 1992) (Figure 2).

The few studies regarding plant zonation in irregular tropical estuaries suggest a zonation with larger occurrence zones and niche overlapping (Costa et al., 2003). In the Massaguaçu River estuary, many species presented large occurrence zones in this study. Eleven out of twelve species occurred in at least three banks, and seven were present in both extremities. Thus, this zonation pattern is consistent with what has been proposed for irregular estuaries. The large occurrence zones suggest that, for most plants, the estuary abiotic conditions are not a limiting factor, and the environment acts only as a regulator in the competitive interactions. Therefore, it would be expected that the importance of the environment to plant zonation in an irregular estuary would be relatively the same, regardless of the conditions. Nevertheless, that was not what we 


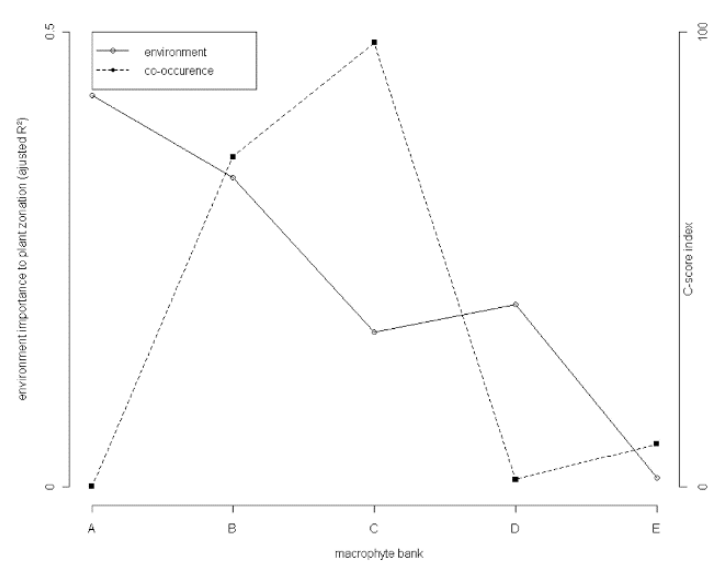

Figure 2. Environmental importance for plan zonation and species co-occurrence in the five main macrophytes banks. The continuous line represents the relative importance of the environment for plant zonation in the Massaguaçu River estuary. The dotted line represents the co-occurrence (c-score) among the most abundant species of the estuary. Values (expressed in \%) are the number of times the observed data presented a smaller number of checkerboard pairs than expected by chance over 10000 randomizations. Thus, higher values indicate higher co-occurrence between species.

observed. As proposed for temperate regular estuaries, the environmental importance is directly related to the tidal influence. The irregularity of flooding, and thus, environmental unpredictability, allowed species to establish occasion spots all over the estuary, but the main portions of the populations are concentrated in a much thinner zone. Crinum americanum $\mathrm{L}$, for example, was observed to occur along all gradients but is clearly concentrated in the more saline banks. Eleocharis interstincta (Vahl) Roem. \& Schult. is widely distributed in the estuary as well, but its population is almost three-fold larger in the less saline banks. Thus, we concluded that the environmental conditions of the Massaguaçu River estuary lead to large occurrence zones. However, in terms of the relative importance of environment, the observed plant zonation pattern is in agreement with what would be expected for a tradeoff-explained zonation environment.

\section{Acknowledgements}

JPNR acknowledges the Conselho Nacional de Desenvolvimento Cientifico (CNPq) for funding this research. RSM and LKT acknowledge the Coordenação de Aperfeiçoamento de Pessoal de Nivel Superior (CAPES) for the scholarship. We also would like to thank Mateus Silveira for all the field support.

\section{References}

CASTILLO, JM., FERNÁNDEZ-BACO, L., CASTELLANOS, EM., LUQUE, CJ., FIGUEROA, ME. and DAVY, AJ., 2000. Lower limits of Spartina densiflora and S. maritima in a Mediterranean salt marsh determined by different ecophysiological tolerances. Journal of Ecology, vol. 88, no. 5, p. 801-812. http://dx.doi. org/10.1046/j.1365-2745.2000.00492.x.

COSTA, CSB., MARANGONI, JC. and AZEVEDO, AMG., 2003. Plant zonation in irregularly flooded salt marshes: relative importance of stress tolerance and biological interactions. Journal of Ecology, vol. 91, no. 6, p. 951-965. http://dx.doi. org/10.1046/j.1365-2745.2003.00821.x.

CRAIN, CM., SILLIMAN, BR., BERTNESS, SL. and BERTNESS, MD., 2004. Physical and biotic drivers of plant distribution across estuarine salinity gradients. Ecology, vol. 85, no. 9, p. 2539-2549. http://dx.doi.org/10.1890/03-0745.

GOTELLI, NJ. and ENTSMINGER, GL., 2001. EcoSim: null models software for ecology. Jericho: Acquired Intelligence Inc. and Kesey-Bear. Version 7.

GREENWOOD, ME. and MACFARLANE, GR., 2009. Effects of salinity on competitive interactions between two Juncus species. Aquatic Botany, vol. 90, no. 1, p. 23-29. http://dx.doi. org/10.1016/j.aquabot.2008.05.001.

GRIME, JP., 1977. Evidence for the existence of three primary strategies in plants and its relevance to ecological and evolutionary theory. American Naturalist, vol. 111, no. 982, p. 1169-1194. http://dx.doi.org/10.1086/283244.

HORNER-DEVINE, MC., SILVER, JM., LEIBOLD, MA., BOHANNAN, BJM., COLWELL, RK., FUHRMAN, JA., GREEN, JL., KUSKE, CR., MARTINY, JBH., MUYZER, G., OVREÅS, L., REYSENBACH, A-L. and SMITH, VH., 2007. A comparison of taxon co-occurrence patterns for macro- and microorganisms. Ecology, vol. 88, no. 6, p. 1345-1353. http:// dx.doi.org/10.1890/06-0286. PMid:17601127.

KING, WM., WILSON, JB. and SYKES, MT., 1990. A vegetation zonation from saltmarsh to riverbank in New Zealand. Journal of Vegetation Science, vol. 1, no. 3, p. 411-418. http://dx.doi. org/10.2307/3235718.

KOZLOWSKI, T.T., 1997. Responses of woody plants to flooding and salinity. Tree Physiology, vol. 1, no. 1, p. 1-29. http://dx.doi. org/10.1093/treephys/17.7.490.

LALIBERTÉ, E., PAQUETTE, A., LEGENDRE, P. and BOUCHARD, A., 2009. Assessing the scale-specific importance of niches and other spatial processes on beta diversity: a case study from a temperate forest. Oecologia, vol. 159, no. 2, p. 377-388. http://dx.doi.org/10.1007/s00442-008-1214-8. PMid:19018575.

NEWMAN, EI., 1973. Competition and diversity in herbaceous vegetation. Nature, vol. 244 , no. 5414 , p. 310 . http://dx.doi. org/10.1038/244310a0.

OTTE, ML., 2001. What is stress to a wetland plant. Environmental and Experimental Botany, vol. 46, no. 3, p. 195-202. http://dx.doi. org/10.1016/S0098-8472(01)00105-8.

PEEL, MC., FINLAYSON, BL. and MCMAHON, TA., 2007. Updated world map of the Köppen-Geiger climate classification. Hydrology and Earth System Sciences, vol. 11, no. 5, p. 16331644. http://dx.doi.org/10.5194/hess-11-1633-2007.

PENNINGS, SC. and CALLAWAY, RM., 1992. Salt marsh plant zonation: the relative importance of competition and physical factors. Ecology, vol. 73, no. 2, p. 681-690. http://dx.doi. org/10.2307/1940774.

PENNINGS, SC., GRANT, M-B. and BERTNESS, MD., 2005. Plant zonation in low-latitude salt marshes: disentangling the roles of flooding, salinity and competition. Journal of Ecology, 
vol. 93, no. 1, p. 159-167. http://dx.doi.org/10.1111/j.13652745.2004.00959.x

PEYRE, MKGL., GRACE, JB., HAHN, E. and MENDELSSOHN, IA., 2001. The importance of competition in regulating plant species abundance along a salinity gradient. Ecology, vol. 82, no. 1, p. 62-69. http://dx.doi.org/10.2307/2680086.

$\mathrm{R}$ Development Core Team, 2008. R: a language and environment for statistical computing. Vienna: R Foundation for Statistical Computing.

RIBEIRO, JPN., MATSUMOTO, RS., TAKAO, LK., PERET, AC. and LIMA, MIS., 2011a. Spatial distribution of Crinum americanum L. in tropical blind estuary: hydrologic, edaphic and biotic drivers. Environmental and Experimental Botany, vol. 71, no. 2, p. 287-291. http://dx.doi.org/10.1016/j.envexpbot.2010.12.011.

RIBEIRO, JPN., TAKAO, LK., MATSUMOTO, RS., URBANETZ, C. and LIMA, MIS., 2011b. Plantae, aquatic, amphibian and marginal species, Massaguaçu River Estuary, Caraguatatuba, São Paulo, Brazil. Check List, vol. 7, no. 2, p. 133-138.

RIBEIRO, JPN., SAGGIO, A. and LIMA, MIS., 2013. The effects of artificial sandbar breaching on the macrophyte communities of an intermittently open estuary. Estuarine, Coastal and Shelf Science, vol. 121-122, p. 33-39. http://dx.doi.org/10.1016/j. ecss.2013.02.007.

RUSSELL, PJ., FLOWERS, TJ. and HUTCHINGS, MJ., 1985. Comparison of niche breadths and overlaps of halophytes on salt marshes of differing diversity. Vegetatio, vol. 61, no. 1-3, p. 171-178. http://dx.doi.org/10.1007/BF00039822.

SORRELL, BK. and TANNER, CC., 2000. Convective gas flow and internal aeration in Eleocharis sphacelata in relation to water depth. Journal of Ecology, vol. 88, no. 5, p. 778-789. http://dx.doi. org/10.1046/j.1365-2745.2000.00493.x.

TILMAN, D., 1982. Resource competition and community structure. New Jersey: Princeton University Press. 296 p.

TOUCHETTE, BW., 2006. Salt tolerance in a Juncus roemerianus brackish marsh: Spatial variations in plant water relations. Journal of Experimental Marine Biology and Ecology, vol. 337, no. 1, p. 1-12. http://dx.doi.org/10.1016/j.jembe.2006.05.011.

UNGAR, I., 1998. Are biotic factors significant in influencing the distribution of halophytes in saline habitats? Botanical Review, vol. 64, no. 2, p. 176-199. http://dx.doi.org/10.1007/BF02856582.

VINCE, SW. and ALLISON, AS., 1984. Plant zonation in an Alaskan Salt Marsh: I. Distribution, abundance and environmental factors. Journal of Ecology, vol. 72, no. 2, p. 651-667. http:// dx.doi.org/10.2307/2260074.

WIENS, JA., 1977. On competition and variable environments. American Scientist, vol. 65, no. 5, p. 590-597.

WOLANSKI, E., 2007. Estuarine ecohydrology. Amsterdam: Elsevier. $168 \mathrm{p}$. 